Volume 10, Nomer 04, 2020

\title{
Penerapan Program Pemberdayaan Keluarga Sebagai Upaya Meningkatkan Status Fungsional Klien dan Kesiapan Keluarga Merawat Klien Stroke
}

\author{
Liya Arista ${ }^{1}$, Elly Nurachmah ${ }^{2}$, Tuti Herawati ${ }^{3}$ \\ ${ }_{1,2,3}$ Departemen Keperawatan Medikal Bedah \\ Fakultas Ilmu Keperawatan Universitas Indonesia \\ Email: liyaarista@ui.ac.id ${ }^{1}$, ellynur08@yahoo.co.id ${ }^{2}$
}

\begin{abstract}
Abstrak
Pendahuluan: Stroke merupakan kondisi hilangnya fungsi otak karena gangguan aliran darah otak terjadi lebih dari 24 jam. Stroke berdampak fisik maupun mental sehingga klien stroke bergantung kepada keluarga serta membutuhkan perawatan dan pemulihan jangka panjang.

Tujuan: Tujuan penelitian untuk mengetahui pengaruh program pemberdayaan keluarga terhadap status fungsional klien dan kesiapan keluarga merawat klien stroke.

Metode: Desain penelitian quasi experiment dengan pendekatan control group pretest posttest design pada 25 responden meliputi 12 orang kelompok kontrol dan 13 orang kelompok intervensi.

Hasil: Hasil penelitian menunjukkan tidak terdapat perbedaan yang bermakna status fungsional klien antara kelompok kontol dan intervensi setelah program pemberdayaan. Namun, terdapat perbedaan yang bermakna kesiapan keluarga merawat klien stroke antara kelompok kontrol dan intervensi ( $\mathrm{p}=0,004$ pada $\alpha=0,05)$.

Kesimpulan: Oleh karena itu, pemberian program pemberdayaan keluarga direkomendasikan sebagai intervensi keperawatan untuk mempersiapkan keluarga melaksanakan perawatan terutama ketika klien stroke pulang ke rumah.
\end{abstract}

Kata kunci: pemberdayaan keluarga, stroke, status fungsional, kesiapan keluarga

\section{Pendahuluan}

Stroke merupakan penyebab kematian ketiga di negara maju setelah penyakit jantung dan kanker. Sekitar 800.000 masyarakat di Amerika mengalami stroke tiap tahunnya dan tiap empat menit satu orang Amerika meninggal karena stroke. ${ }^{1}$ Stroke juga masih

\begin{abstract}
Introduction: Stroke is a condition of brain function loss due to disturbance in cerebral blood flow that occurs more than 24 hours. The difficulties and dysfunction are caused by brain damage entail long-term disorders of physical and mental balance, so that the patients depend on their families.

Objective: The aim of this study was to assess the impact of the family empowerment program on the functional status of patients after stroke and also family preparedness to taking care the patients at home.

Method: The study design was a quasi-experiment design with pretest-posttest control group approach using 25 respondents. Groups were divided into a control group $(n=12)$ and intervention group $(n=13)$.

Result: The results showed that is no significant difference between functional status in both groups after the intervention, but there is a significant difference in family preparedness to taking care for stroke survivors between the control and intervention groups ( $p=0.004$ at $\alpha=0.05)$.

Conculsion: Based on the results, the provision of family empowerment program as a preparation for discharge planning could be one of the nursing interventions for families to giving a care for stroke survivors at home.
\end{abstract}

Keywords: family empowerment, stroke, functional status, family preparedness.

menjadi masalah yang sangat serius di Asia, yang memiliki lebih dari $60 \%$ populasi dunia, dan banyak terjadi di negara dengan ekonomi yang masih "berkembang". Riskesdas tahun 2018 menunjukkan prevalensi stroke di Indonesia sekitar 10,9 mil per 1000 penduduk, 
angka ini meningkat dibandingkan dengan tahun 2007 dimana prevalensi stroke sekitar 8,3 per 1000 penduduk meskipun sedikit mengalami penurunan dibandingkan data tahun 2013 yaitu 12,1 per mil.

Stroke menjadi salah satu penyebab kematian di RS. Sebesar 15\% penyebab kematian di RS adalah kasus stroke yang artinya 1 dari 7 kematian disebabkan oleh stroke dengan tingkat kecacatan mencapai 65\%. ${ }^{4}$ Data dari bagian rekam medis RSUP Fatmawati menampilkan bahwa jumlah penderita stroke selama dua tahun terakhir mengalami peningkatan. Pada tahun 2013 mencapai 558 kasus. Jumlah ini meningkat dibandingkan dengan tahun 2012. Stroke berdampak pada ketidakmampuan fisik dalam melakukan aktivitas. Penelitian Haghgoo, Pazuki, Hosseini, dan Rassafani (2013) menyebutkan bahwa 70\% klien stroke mengalami ketidakmampuan dalam aktivitas harian. Ketidakmampuan tersebut paling banyak terjadi pada klien dengan keterbatasan motorik.

Peran keluarga dalam perawatan klien stroke sangat penting. Kesulitan klien dalam melaksanakan aktivitas sehari-hari mengakibatkan klien sangat bergantung pada keluarga. Keluarga atau caregiver pada umumnya mendapat tanggung jawab besar terhadap perawatan dengan berbagai tantangan yang dihadapi. Perasaan tidak siap sering dirasakan dan akan berdampak terhadap kesejahteraan keluarga serta dapat berdampak negatif pula terhadap kualitas asuhan yang diberikan oleh keluarga kepada klien.

Kurangnya informasi dan pemahaman yang diperoleh keluarga serta kurangnya perlibatan keluarga dalam proses perencanaan pulang berdampak pada ketidaksiapan keluarga dalam proses perawatan di rumah sakit maupun dalam persiapan untuk perawatan di rumah. Hal ini terjadi karena tenaga kesehatan cenderung fokus pada penanganan medis dibandingkan perlibatan keluarga. Salah satu upaya yang dapat dilakukan untuk melibatkan keluarga adalah melalui program pemberdayaan keluarga. Sampai saat ini masih belum ada program pemberdayaan keluarga yang secara efektif dapat meningkatkan kemampuan fungsional klien serta kesiapan keluarga dalam merawat klien dalam merawat klien di rumah sakit. Tujuan dari penelitian ini adalah menghasilkan suatu panduan perawatan pasien di rumah sehingga pasien dan keluarga dapat merasa lebih siap dalam menjalani proses rehabilitasi pasca stroke di rumah.

\section{Metode}

Penelitian ini menggunakan desain kuasi-eksperimen dengan pendekatan control group pretest posttest design. Terdapat dua kelompok yaitu kelompok intervensi di RSUD Pasar Rebo dan kelompok kontrol di RSUP Fatmawati. Kelompok intervensi diberikan perlakuan berupa program pemberdayaan keluarga sedangkan kelompok kontrol hanya mendapatkan perlakuan standar yang sesuai dengan Standar Prosedur Operasional (SPO) di RSUP Fatmawati. Penelitian ini dilakukan untuk mengetahui apakah ada pengaruh setelah dilakukan perlakuan pada kelompok intervensi. Kemudian dua minggu setelah perlakuan diberikan, dilakukan penilaian status fungsional kepada klien dan kesiapan keluarga dalam melakukan perawatan dan dibandingkan apakah ada perbedaan status fungsional dan kesiapan keluarga pada kelompok intervensi dan kelompok kontrol.

Penelitian dilaksanakan pada bulan Mei hingga Juni selama kurang lebih 5 minggu. Populasi dalam penelitian ini adalah semua pasien stroke, baik iskemik maupun perdarahan yang menjalani perawatan di rumah sakit. Sedangkan, sampel penelitian ini adalah klien stroke di ruang rawat inap RSUD Pasar Rebo dan RSUP Fatmawati Jakarta yang memenuhi kriteria inklusi dan kriteria ekslusi. Kriteria inklusi sampel antara lain klien dengan diagnosa medis stroke (iskemik dan perdarahan), lama hari rawat $>3$ hari, GCS $>10$, TTV dalam batas normal dan stabil, klien mengalami ketergantungan dalam pemenuhan kebutuhan sehari-hari, klien 
ditemani oleh keluarga atau informal caregiver, keluarga klien dapat baca dan tulis. Sedangkan riteria ekslusi sampel antara lain, klien yang dirawat oleh caregiver yang sudah pernah mendapat pelatihan, klien yang tinggal di wilayah luar jabodetabek atau yang tidak bersedia didatangi ke rumah untuk follow up.

Cara pengambilan sampel dengan Consecutive sampling. Besar sampel yang diperoleh berdasarkan rumus perhitungan sampel penelitian analitik numerik rerata dua populasi adalah sebesar 25 responden penelitian untuk kelompok kontrol dan intervensi. Penelitian ini telah melewati Uji Etik dari Komite Etik FIK UI. Adapun prinsip etika yang digunakan dalam penelitian ini meliputi: Beneficience, self determination, justice, dan privacy. Peneliti menjelaskan manfaat penelitian kepada responden. Peneliti juga meyakinkan bahwa partisipasi dan informasi yang diberikan tidak akan merugikan mereka dengan tetap menjaga kerahasiaan hasil informasi. Selain itu peneliti juga meyakinkan bahwa penerapan program pemberdayaan keluarga ini tidak akan mengganggu proses penatalaksanaan stroke di ruang rawat.

Responden mempunyai hak untuk memutuskan secara sukarela apakah akan ikut berpartisipasi pada penelitian atau tidak. Jika klien stroke dalam kondisi penurunan kesadaran atau mengalami masalah kognitif, maka keluarga berhak menjadi wali untuk memberikan keputusan. Peneliti akan menghormati keputusan responden dan tidak akan memaksakan untuk turut dalam penelitian. Responden dapat mengundurkan diri dari penelitian. Semua hal tersebut akan diawali dengan pemberian informasi yang sejelas-jelasnya terkait penelitian mulai dari tujuan, manfaat hingga prosedur lengkapnya.

Alat pengumpulan data yang digunakan dalam penelitian ini antara lain adalah buku panduan perawatan stroke oleh keluarga, kuesioner data demografi, pengkajian status fungsional yang merupakan modifikasi dari NIHSS dan Barthel Indeks yang berisi komponen pengkajian fisik, neurologis dan kemampuan ADL, kuesioner yang terakhir adalah kuesioner tentang kesiapan keluarga dalam merawat klien stroke yang berisi 16 pertanyaan. Selain itu, peneliti juga menggunakan lembar observasi kegiatan keluarga serta lembar evaluasi kemampuan keluarga dalam melakukan perawatan terhadap klien stroke. Uji Validitas dan Reliabilitas untuk Instrumen kesiapan keluarga/caregiver dalam melakukan perawatan klien stroke memperoleh nilai alpha cronbach sebesar 0,784 .

\section{Hasil}

Tabel 1. Responden berdasarkan Usia ( $\mathrm{N}=25)$

\begin{tabular}{lccc}
\hline & Kel & n & Mean \pm SD \\
\hline Usia & Kontrol & 12 & $60,08 \pm 12,264$ \\
\cline { 2 - 4 } klien & Intervensi & 13 & $61,85 \pm 11,553$ \\
\cline { 2 - 4 } Stroke & Total & 25 & $60,96 \pm 11,708$ \\
\hline
\end{tabular}

Hasil analisis pada tabel 1 menunjukkan bahwa rata-rata usia klien stroke yang menjadi responden di RSUD Pasar Rebo adalah 61,85. Sedangkan rata-rata usia klien stroke yang menjadi responden di RSUP Fatmawati adalah 60,08 tahun.

Tabel 2. Distribusi Klien Stroke berdasarkan Jenis Kelamin $(\mathrm{N}=25)$

\begin{tabular}{lcccccc}
\hline \multirow{2}{*}{ Variabel } & \multicolumn{2}{c}{ Kontrol } & \multicolumn{2}{c}{ Intervensi } & \multicolumn{2}{c}{ Total } \\
\cline { 2 - 7 } & $\mathbf{n}$ & $\%$ & $\mathbf{n}$ & $\%$ & $\mathbf{n}$ & $\%$ \\
\hline Jenis & & & & & & \\
Kelamin & & & & & & \\
\hline Laki-laki & 7 & 58,3 & 8 & 61,5 & 15 & 60 \\
\hline Perempuan & 5 & 41,7 & 5 & 38,5 & 10 & 40 \\
\hline
\end{tabular}

Tabel 2 menunjukkan bahwa sebagian besar klien stroke yang dirawat di RSUD Pasar Rebo berjenis kelamin laki-laki $(61,5 \%)$. Hal yang sama ditemukan di RSUP Fatmawati dimana sebagian besar klien stroke yang dirawat berjenis kelamin laki-laki $(61,5 \%)$.

Tabel 3. Distribusi Klien Stroke berdasarkan Karakteristik Medis ( $\mathrm{N}=25)$ 


\begin{tabular}{|c|c|c|c|c|c|c|}
\hline \multirow[t]{2}{*}{ Variabel } & \multicolumn{2}{|c|}{ Kontrol } & \multicolumn{2}{|c|}{ Intervensi } & \multicolumn{2}{|c|}{ Total } \\
\hline & $\mathbf{n}$ & $\%$ & $\mathbf{n}$ & $\%$ & $\mathbf{N}$ & $\%$ \\
\hline $\begin{array}{l}\text { Jenis } \\
\text { Stroke }\end{array}$ & & & & & & \\
\hline Iskemik & 10 & 83,4 & 11 & 84,6 & 21 & 84 \\
\hline Hemoragik & 2 & 16,7 & 2 & 15,4 & 4 & 16 \\
\hline $\begin{array}{l}\text { Frekuensi } \\
\text { Stroke }\end{array}$ & & & & & & \\
\hline pertama & 7 & 58,3 & 10 & 76,9 & 17 & 68 \\
\hline berulang & 5 & 41,7 & 3 & 23,1 & 8 & 32 \\
\hline $\begin{array}{l}\text { Admission } \\
\text { time }\end{array}$ & & & & & & \\
\hline $0-<3$ jam & 0 & 0 & 1 & 7,7 & 1 & 4 \\
\hline $3-<6$ jam & 3 & 25 & 3 & 23,1 & 6 & 24 \\
\hline $\begin{array}{l}6-<12 \\
\text { jam }\end{array}$ & 5 & 41,7 & 4 & 30,8 & 9 & 36 \\
\hline$>12$ jam & 4 & 33,3 & 5 & 38,5 & 9 & 36 \\
\hline
\end{tabular}

Tabel 3 menjelaskan sebagian besar klien stroke di RSUD Pasar Rebo menderita stroke iskemik serangan pertama dan waktu antara terjadinya serangan hingga mendapat penangan di RS adalah> 12 jam sama dengan dengan responden di RSUP Fatmawati sebagian besar menderita stroke iskemik serangan pertama. Namun untuk waktu antara terjadinya serangan hingga mendapat penanganan di RS sama antara 6 - kurang dari 12 jam (36\%) dan 12 jam (36\%).

Tabel 4. Responden berdasarkan Usia Keluarga Klien Stroke $(\mathrm{N}=25)$

\begin{tabular}{lccc}
\hline Variabel & Kelompok & $\mathbf{n}$ & Mean \pm SD \\
\hline \multirow{2}{*}{ Usia } & Kontrol & 12 & $47,67 \pm 12,213$ \\
\cline { 2 - 4 } Keluarga & Intervensi & 13 & $50,85 \pm 11,305$ \\
\cline { 2 - 4 } & Total & 25 & $49,32 \pm 11,614$ \\
\hline
\end{tabular}

Hasil analisis pada tabel 4 menunjukkan bahwa rata-rata usia keluarga klien stroke yang menjadi responden di RSUD Pasar Rebo adalah 50,85 tahun sedangkan rata-rata usia keluarga klien stroke yang menjadi responden di RSUP Fatmawati adalah 46,69 tahun

Tabel 5. Distribusi Responden berdasarkan Karakteristik Demografi Keluarga Klien Stroke $(\mathrm{N}=25)$

\begin{tabular}{|c|c|c|c|c|c|c|}
\hline \multirow{2}{*}{ Variabel } & \multicolumn{2}{|c|}{ Kontrol } & \multicolumn{2}{|c|}{ Intervensi } & \multicolumn{2}{|c|}{ Total } \\
\hline & $\mathrm{n}$ & $\%$ & $\mathbf{n}$ & $\%$ & & $\%$ \\
\hline \multicolumn{7}{|l|}{$\begin{array}{l}\text { Jenis } \\
\text { Kelamin }\end{array}$} \\
\hline Laki-laki & 4 & 33,3 & 2 & 15,4 & 6 & 24 \\
\hline Perempuan & 8 & 66,7 & 11 & 84,6 & 19 & 76 \\
\hline \multicolumn{7}{|l|}{$\begin{array}{l}\text { Tingkat } \\
\text { Pendidikan }\end{array}$} \\
\hline Lulus SD & 4 & 33,3 & 1 & 7,7 & 5 & 20 \\
\hline Lulus SMP & 1 & 8,3 & 2 & 15,4 & 3 & 12 \\
\hline Lulus SMA & 6 & 50 & 7 & 53,8 & 13 & 52 \\
\hline $\begin{array}{l}\text { Perguruan } \\
\text { Tinggi }\end{array}$ & 1 & 8,3 & 3 & 23,1 & 4 & 16 \\
\hline \multicolumn{7}{|l|}{$\begin{array}{l}\text { Status } \\
\text { Pernikahan }\end{array}$} \\
\hline $\begin{array}{l}\text { Belum } \\
\text { Menikah }\end{array}$ & 0 & 0 & 1 & 7,7 & 1 & 4 \\
\hline Menikah & 11 & 91,7 & 12 & 92,3 & 23 & 92 \\
\hline Janda/ Duda & 1 & 8,3 & 0 & 0 & 1 & 4 \\
\hline $\begin{array}{l}\text { Hubungan } \\
\text { dengan klien } \\
\text { stroke }\end{array}$ & & & & & & \\
\hline $\begin{array}{l}\text { Suami/istri } \\
\text { Anak }\end{array}$ & $\begin{array}{l}7 \\
5\end{array}$ & $\begin{array}{l}58,3 \\
41,7\end{array}$ & $\begin{array}{l}8 \\
4\end{array}$ & $\begin{array}{l}61,5 \\
30,8\end{array}$ & $\begin{array}{c}15 \\
9\end{array}$ & $\begin{array}{l}60 \\
36\end{array}$ \\
\hline $\begin{array}{l}\text { kandung } \\
\text { Saudara } \\
\text { kandung }\end{array}$ & 0 & 0 & 1 & 7,7 & 1 & 4 \\
\hline $\begin{array}{l}\text { Pekerjaan } \\
\text { Tidak } \\
\text { Bekerja/IRT }\end{array}$ & 8 & 66,7 & 9 & 69,2 & 17 & 68 \\
\hline Bekerja & 4 & 33,3 & 4 & 30,8 & 8 & 32 \\
\hline
\end{tabular}

Tabel 5 menggambarkan karakteristik keluarga klien stroke di RSUD Pasar Rebo dan RSUP Fatmawati berdasarkan jenis kelamin, tingkat pendidikan, pekerjaan, status perkawinan dan kondisi stres yang dialami oleh keluarga. Sebagian besar keluarga yang merawat klien stroke berjenis kelamin perempuan (76\%), telah menikah (92\%) dengan pendidikan SMA (52\%) dan tidak bekerja/IRT (68\%).

Tabel 6. Analisis Rata-rata Status Fungsional Klien Stroke 


\begin{tabular}{|c|c|c|c|c|c|}
\hline & $\mathbf{n}$ & Mean \pm SD & SE & $\mathbf{t}$ & p value \\
\hline $\begin{array}{l}\text { Kelompok } \\
\text { Intervensi }\end{array}$ & & & & & \\
\hline $\begin{array}{l}\text { Pre test } \\
\text { Post test }\end{array}$ & 13 & $\begin{array}{l}22,77 \pm 8,594 \\
32,00 \pm 7,280\end{array}$ & $\begin{array}{l}2,384 \\
2,019\end{array}$ & $-11,74$ & $0,0001^{*}$ \\
\hline $\begin{array}{c}\text { Kelompok } \\
\text { Kontrol } \\
\text { Pre test } \\
\text { Post test }\end{array}$ & 12 & $\begin{array}{l}22,92 \pm 9,130 \\
31,42 \pm 6,802\end{array}$ & $\begin{array}{l}2,636 \\
1,964\end{array}$ & $-8,005$ & $0,0001^{*}$ \\
\hline $\begin{array}{l}\text { Post test } \\
\text { Kelompok } \\
\text { Intervensi }\end{array}$ & 13 & $32,00 \pm 7,280$ & 2,019 & $-0,20^{\prime}$ & 0,838 \\
\hline $\begin{array}{c}\text { Kelompok } \\
\text { Kontrol }\end{array}$ & 12 & $31,42 \pm 7,280$ & 2,019 & & \\
\hline
\end{tabular}

Berdasarkan Tabel 6, status fungsional klien stroke kelompok intervensi dan kelompok kontrol berdasarkan hasil uji statik didapatkan nilai $\mathrm{p}=0,0001<\alpha \quad 0,05$ maka dapat disimpulkan bahwa ada perbedaan yang bermakna antara sebelum dan sesudah dilakukan program pemberdayaan keluarga. Rata-rata status fungsional klien stroke setelah perlakuan pada kelompok intervensi lebih tinggi dibandingkan dengan kelompok kontrol. Namun hasil uji statistik didapatkan nilai $\mathrm{p}=0,838$ yang bermakna bahwa tidak ada perbedaan yang bermakna antara status fungsional setelah perlakuan pada kelompok kontrol dan kelompok intervensi.

Kelompok intervensi memiliki nilai status fungsional lebih tinggi dibandingkan dengan kelompok kontrol namun berdasarkan hasil uji statistik diperoleh nilai $\mathrm{p}>0,05$. Artinya, tidak terdapat perbedaan yang bermakna antara peningkatan status fungsional kelompok yang memperoleh program pemberdayaan keluarga dengan kelompok yang memperoleh perlakuan sesuai dengan SPO RS.

Tabel 7. Analisis Rata-rata Kesiapan Keluarga merawat Klien Stroke

\begin{tabular}{cccccc}
\hline $\begin{array}{c}\text { Kesiapan } \\
\text { Keluarga }\end{array}$ & $\mathbf{n}$ & Mean \pm SD & SE & $\mathbf{t}$ & p value \\
\hline $\begin{array}{c}\text { Kelompok } \\
\text { Intervensi }\end{array}$ & & & & \\
$\begin{array}{c}\text { Pre test } \\
\text { Post test }\end{array}$ & 13 & $38,15 \pm 4,793$ & 1,329 & $-10,773$ & $0,0001^{*}$ \\
\hline
\end{tabular}

\begin{tabular}{cccccc}
\hline $\begin{array}{c}\text { Kelompok } \\
\begin{array}{c}\text { Kontrol } \\
\text { Pre test }\end{array}\end{array}$ & $37,83 \pm 4,174$ & 1,205 & & \\
$\begin{array}{c}\text { Post test } \\
\text { Post test }\end{array}$ & $41,00 \pm 5,152$ & 1,487 & -3644 & $0,004^{*}$ \\
\hline $\begin{array}{c}\text { Intervensi } \\
\text { Kontrol }\end{array}$ & 13 & $46,46 \pm 3,307$ & 0,917 & $-3,180$ & $0,004^{*}$ \\
\hline Selisih & $41,00 \pm 5,152$ & 1,487 & & \\
$\begin{array}{c}\text { Kesiapan } \\
\text { keluarga }\end{array}$ & 13 & $8,31 \pm 2,780$ & 0,771 & $-4,440$ & $0,0001^{*}$ \\
$\begin{array}{c}\text { Intervensi } \\
\text { Kontrol }\end{array}$ & $3,17 \pm 3,010$ & 0,868 & & \\
\hline
\end{tabular}

Berdasarkan tabel 7 Rata-rata kesiapan keluarga merawat klien stroke pada kelompok intervensi dan kontrol berdasarkan hasil uji statik didapatkan nilai $\mathrm{p}=0,0001<\alpha \quad 0,05$ maka dapat disimpulkan bahwa ada perbedaan yang bermakna antara sebelum dan sesudah dilakukan program pemberdayaan keluarga. Rata-rata kesiapan keluarga merawat klien stroke pada kelompok intervensi lebih tinggi dibandingkan dengan kelompok kontrol.Hasil uji statistik didapatkan nilai $\mathrm{p}=0,002<\alpha 0,05$ yang bermakna bahwa ada perbedaan yang bermakna antara kesiapan eluarga merawat klien stroke setelah perlakuan pada kelompok kontrol dan kelompok intervensi.

Kelompok intervensi memiliki selisih tingkat kesiapan keluarga lebih tinggi dibandingkan dengan kelompok kontrol. Hasil uji statistik diperoleh nilai $p=0,0001<\alpha$. Artinya, terdapat perbedaan yang bermakna antara selisih kesiapan keluarga merawat klien stroke pada kelompok yang memperoleh program pemberdayaan keluarga dengan kelompok yang memperoleh perlakuan sesuai dengan SPO RS.

\section{Pembahasan}

Status fungsional merupakan kemampuan individu melakukan aktivitas harian dalam memenuhi kebutuhan dasar, melaksanakan peran, serta mempertahankan kesehatan dan kesejahteraan. Komponen status fungsional mencakup kondisi fisik maupun kinerja fungsional. ${ }^{\top}$ Pada penelitian ini peneliti memodifikasi dua instrumen yaitu NIHSS dan Barthel Index dalam mengukur status. Klien stroke akan mengalami masalah 
khusus akibat disabilitas fisik dan mental yang membutuhkan pelaksanaan rehabilitasi. Teori tersebut terbukti pada penelitian ini dimana masalah fungsional yang paling sering dialami klien stroke adalah hemiparesis, disatria serta ketergantungan penuh terhadap orang lain. Hampir seluruh klien stroke yang menjadi responden memiliki salah satu dari ketiga masalah tersebut.

Hasil metanalisis dari Wist, S., Clivaz, J., \& Sattelmayer, M. (2016) menemukan bahwa kelemahan ekstremitas merupakan komplikasi yang paling umum terjadi setelah serangan stroke. Sekitar 70\% penderita stroke mengalami kelemahan baik pada ekstremitas atas maupun bawah. Hal ini sesuai dengan temuan pada penelitian ini, sebagian besar klien stroke mengalami masalah kelemahan pada ekstremitas yang pada akhirnya berakibat pada keterbatasan dalam melakukan ADL.'

Penelitian ini juga memperoleh bahwa status fungsional sebelum dan sesudah pemberian program pemberdayaan keluarga mengalami peningkatan yang bermakna pada kelompok kontrol $(\mathrm{p}=0,0001)$ maupun kelompok intervensi $(\mathrm{p}=0,0001)$. Sehingga dapat disimpulkan bahwa status fungsional klien stroke setelah perlakuan lebih tinggi dibandingkan dengan sebelum perlakuan pada kedua kelompok dalam penelitian ini. Progran pemberdayaan keluarga yang dilakukan pada kelompok intervensi tidak memberi dampak yang signifikan terhadap perubahan status fungsional klien stroke. Hal ini dibuktikan dengan tidak ditemukannya perbedaan yang bermakna antara status fungsional sesudah pemberian program pemberdayaan keluarga pada kelompok intervensi dengan kelompok kontrol ( $p=0,738 ; \alpha=0,05)$. Hasil Penelitian ini sejalan dengan penelitian Hebel, Bieniaszewski dan Kowalewski (2014) tentang pengaruh pendidikan kesehatan kepada caregiver terhadap peningkatan status fungsional klien pasca stroke iskemik. Status fungsional diukur setelah 3 bulan dan 12 bulan pasca pemberian pendidikan kesehatan. Penelitian tersebut menemukan bahwa partisipasi caregiver dalam proses pendidikan kesehatan tidak berdampak signifikan terhadap peningkatan status fungsional klien $(\mathrm{p}=0,176 ; \alpha=0,05){ }^{10}$

Penelitian serupa dari Forster, et al (2013) yang melakukan penelitian terkait penerapan training programme for caregivers of inpatients after stroke (TRACS) terhadap 450 klien stroke beserta caregiver nya di kelompok intervensi dan 478 di kelompok kontrol. Penelitian tersebut menemukan bahwa tidak terdapat perbedaan yang signifikan kemandirian dalam melakukan ADL maupun skala beban caregiver dalam 6 bulan pasca intervensi. Sehingga dapat disimpulkan bahwa Periode sesaat setelah stroke bukan waktu yang ideal untuk memberikan pelatihan caregiver terstruktur. ${ }^{11}$ Penelitian lain yang dilakukan oleh LópezEspuela, F., et al. (2016) menjelaskan bahwa terdapat perubahan yang signifikan status fungsional pasien 6 bulan pasca stroke. Status fungsional 6 bulan setelah stroke dipengaruhi oleh usia, jenis kelamin, tingkat keparahan stroke, jenis stroke, status baseline, mood, dan risiko sosial. Akan tetapi, kondisi komorbiditas, tingkat sosial ekonomi, dan luas tempat tinggal tidak mempengaruhi status fungsional pasien. Aspek-aspek ini yang perlu dikaji lebih lanjut karena tidak diteliti pada penelitian ini, Selain itu, pengukuran status fungsional yang dilakukan hanya dua minggu setelah perawatan membuat perubahan yang terjadi belum signifikan. ${ }^{12}$

Penyebab peningkatan status fungsional pada kelompok intervensi tidak jauh berbeda dengan kelompok kontrol adalah karena banyak faktor lain yang menjadi prediktor untuk perubahan status fungsional saat klien keluar dari rumah sakit. Penelitian LopezEspeula, et al. (2016) menemukan bahwa status fungsional 6 bulan setelah stroke dipengaruhi oleh usia, jenis kelamin, tingkat keparahan stroke, jenis stroke, status baseline, mood, dan risiko sosial. Kondisi komorbiditas, tingkat sosial ekonomi, dan luas tempat tinggal tidak mempengaruhi status fungsional pasien. ${ }^{12}$

Proses pemulihan setelah stroke dibedakan atas pemulihan neurologis dan 
fungsional. Pemulihan neurologis terjadi di awal pasca stroke sedangkan pemulihan fungsional masih dapat terus terjadi terutama hingga 3-6 bulan pertama pasca stroke. ${ }^{13}$ Inilah yang nantinya akan menjadi fokus dalam pelaksanaan program rehabilitasi yaitu untuk mengoptimalkan kembali kemampuan fungsional. Aspek lain yang diperkirakan menjadi penyebab belum signifikannya perbedaan peningkatan status fungsional antara kelompok kontrol dan intervensi adalah akibat model pemberdayaan yang belum menyeluruh terutama terkait pemberdayaan atau pemberian edukasi terhadap klien stroke itu sendiri. ${ }^{13}$

Pendidikan berkelanjutan tidak hanya berfokus pada penyampaian pengetahuan namun juga memotivasi serta mendorong klien untuk berpartisipasi dalam menghadapi masalah yang berhubungan dengan penyakit, perubahan gaya hidup dan dalam memperoleh hasil akhir yang diharapkan(10). Perubahan gaya hidup yang dapat dilakukan salah satunya adalah terkait aspek nutrisi dan psikososial. Penelitian Purnama dan Saleh (2017) menemukan bahwa pola diet dan stress memiliki hubungan yang signifikan dengan hipertensi. Stroke merupakan salah satu komplikasi dari kondisi hipertensi. ${ }^{14}$

Penelitian ini juga memperoleh bahwa kesiapan keluarga sebelum dan sesudah pemberian program pemberdayaan keluarga mengalami peningkatan yang bermakna baik itu pada kelompok kontrol $(\mathrm{p}=0,001: \alpha=0,05)$ maupun intervensi $(p=0,0001 ; \alpha=0,05)$. Sehingga dapat disimpulkan bahwa terdapat perbedaan yang signifikan antara kesiapan keluarga sebelum dan sesudah perlakuan dimana kesiapan keluarga merawat klien stroke setelah perlakuan lebih tinggi dibandingkan dengan sebelum perlakuan pada kelompok kontrol maupun intervensi.

Temuan peneliti sejalan dengan penelitian yang dilakukan oleh Hager (2010) terkait efek intervensi perencanaan pulang terhadap persepsi kesiapan. Penelitian tersebut menemukan bahwa pada kelompok intervensi hanya 1 dari 7 responden (14\%) merasa tidak siap pasca perawatan di rumah sakit, sedangkan pada kelompok kontrol 4 dari 7 responden $(57,1 \%)$ merasakan tidak siap pasca perawatan di rumah sakit. Pengukuran kesiapan dilakukan 72 jam, 7 hari dan 14 hari pasca rawat. Pada kelompok kontrol, antara kesiapan pada 72 jam dengan 7 hari mengalami perubahan yang signifikan $(\alpha=$ 0,05 ) sedangkan pada kelompok intervensi tingkat kesiapannya cenderung stabil. ${ }^{15}$

Program pemberdayaan keluarga sebagai persiapan rencana pulang memberikan dampak positif terhadap kesiapan keluarga merawat klien stroke. Penelitian ini menemukan bahwa kesiapan keluarga sesudah pemberian program pemberdayaan keluarga pada kelompok intervensi lebih tinggi dibandingkan dengan kelompok kontrol $(\mathrm{p}=$ $0,002 ; \alpha=0,05)$. Hasil dari penelitian ini sejalan dengan temuan oleh Weiss, Yakusheva, dan Bobay (2010) yang menyatakan bahwa pengkajian kesiapan pasien saat discharge planning serta pengajaran yang berkualitas saat persiapan pulang berhubungan erat dengan persepsi kesiapan saat keluar dari rumah sakit.

\section{Kesimpulan}

Penerapan program pemberdayaan keluarga berpengaruh positif terhadap tingkat kesiapan keluarga dalam merawat klien stroke namun tidak berpengaruh secara signifikan terhadap status fungsional klien stroke. Pengukuran dalam rentang yang lebih panjang diperlukan untuk melihat perbedaan yang signifikan terkait nilai status fungsional klien stroke.

\section{Daftar Pustaka}

1. Go AS, Mozaffarian D, Roger VL, Benjamin EJ, Berry JD, Borden WB, et al. Executive summary: heart disease and stroke statistics - 2013 update: a report from the American Heart Association. Circulation. 2013;127(1):143-52.

2. Venketasubramanian N, Yoon BW, Pandian J, Navarro JC. Stroke epidemiology in south, east, and south-east asia: A review. Journal of stroke. 2017;19(3):286.

3. Kemenkes R. Hasil utama riset kesehatan dasar (Riskesdas) 2018. Kementrian 
kesehatan Republik Indonesia Badan Penelitian dan Pengembangan Kesehatan. 2018.

4. DepKes R. Standar Pelayanan Keperawatan Di Rumah sakit. Jakarta; 2015.

5. Haghgoo HA, Pazuki ES, Hosseini AS, Rassafiani M. Depression, activities of daily living and quality of life in patients with stroke. Journal of the neurological sciences. 2013;328(1-2):87-91.

6. Henriksson A, Andershed B, Benzein E, Årestedt K. Adaptation and psychometric evaluation of the Preparedness for Caregiving Scale, Caregiver Competence Scale and Rewards of Caregiving Scale in a sample of Swedish family members of patients with life-threatening illness. Palliative medicine. 2012;26(7):930-8.

7. Schwartz JS. Health services research: translating discovery and research into practice and policy. Clinical and Translational Science: Elsevier; 2017. p. 111-33.

8. Tomašević-Todorović $\mathrm{S}$, Kopčanski $\mathrm{S}$, Mikov A, Bošković K, Popović-Petrović S, Savić M. Functional status of patients after stroke. Medicinski pregled. 2015;68(56):181-6

9. Wist S, Clivaz J, Sattelmayer M. Muscle strengthening for hemiparesis after stroke: A meta-analysis. Annals of Physical and Rehabilitation Medicine. 2016;59(2):11424

10. Hebel K, Bieniaszewski L, Kowalewski W. Health education for stroke patient carers: Does it affect functional status improvement in patients after ischemic stroke? Applied Nursing Research. 2014;27(3):e7-e12.
11. Forster A, Dickerson J, Young J, Patel A, Kalra L, Nixon J, et al. A structured training programme for caregivers of inpatients after stroke (TRACS): a cluster randomised controlled trial and cost-effectiveness analysis. The Lancet. 2013;382(9910):2069-76.

12. López-Espuela F, Pedrera-Zamorano JD, Jiménez-Caballero PE, Ramírez-Moreno JM, Portilla-Cuenca JC, Lavado-García JM, et al. Functional status and disability in patients after acute stroke: a longitudinal study. American journal of critical care. 2016;25(2):144-51.

13. Lee KB, Lim SH, Kim KH, Kim KJ, Kim YR, Chang WN, et al. Six-month functional recovery of stroke patients: a multi-timepoint study. International journal of rehabilitation research Internationale Zeitschrift fur Rehabilitationsforschung Revue internationale de recherches de readaptation. 2015;38(2):173.

14. Purnama A, Saleh R. Perbedaaan Pola Diet dan Stres terhadap Hipertensi Di Rumah Sakit PMI Bogor Tahun 2016. Jurnal Ilmiah Ilmu Keperawatan Indonesia. 2017;7(04):313-21.

15. Hager JS. Effects of a discharge planning intervention on perceived readiness for discharge. 2010.

16. Weiss M, Yakusheva O, Bobay K. Nurse and patient perceptions of discharge readiness in relation to postdischarge utilization. Medical care. 2010:482-6. 